\title{
https://doi.org/10.46813/2021-131-031 \\ TEST PARTICLE SIMULATIONS FOR NON-MAXWELLIAN PLASMA TRANSPORT: DISCRETIZED COLLISIONAL OPERATOR
}

\author{
D.V. Vozniuk, O.A. Shyshkin, I.O. Girka \\ V.N. Karazin Kharkiv National University, Kharkiv, Ukraine
}

The plasma observed in modern fusion devices is very often characterized by strongly non Maxwellian distribution function. That is the direct result of inevitable application of plasma heating techniques, such as neutral beam injection (NBI) and ion/electron cyclotron resonance frequency (ICRF/ECRF) heating, which induce the non Maxwellian fast ions. Another cause of transfer from Maxwellian to non Maxwellian is the reconnection of magnetic field lines followed by formation of magnetic resonant structures like magnetic islands and stochastic layers. One of the basic approaches used to simulate fusion plasma is test particle approach based on a solution of the equations of test particle motion. To make this approach more comprehensive one should take care of plasma particle interactions, i.e. Coulomb collisions in non Maxwellian environment. In present paper the expressions for the discretized collision operator of a general Monte Carlo equivalent form in terms of expectation values and standard deviation for an arbitrary non Maxwellian bulk distribution function are derived. The modification of transport coefficients of impurity ions caused by the transition from the background Maxwellian to non Maxwellian plasma is studied by means of this discretized collision operator. On this purpose, the set of monoenergetic neon test impurities is followed in a toroidal plasma consisting of bulk deuterons and electrons. The non Maxwellian distribution of the bulk is obtained by adding a fraction of energetic particles of the same species. It is demonstrated that a change of collision frequencies of impurities takes place in presence of this energetic fraction leading to a change of impurity neoclassical transport regime.

PACS: 52.20.Dq, 52.25.Xz, 52.55.Pi, 52.65.Cc, 52.65.Pp

\section{INTRODUCTION}

In modern studies the plasma observed in fusion devices like Tokamak and Stellarator is very often characterized by strongly non-Maxwellian distribution. The transition from Maxwellian to non-Maxwellian distribution is caused by the reconnection of the magnetic field lines. Another reason for the transition is the plasma heating by means of neutral beam injection (NBI) and ion/electron cyclotron resonance frequency (ICRF/ECRF) heating that induce the non-Maxwellian fast ions, which interact with bulk and thermal ions. This phenomenon significantly modifies the characteristics of plasma in general that is clearly demonstrated on Tokamak JET [1, 2]. At present time the variety of numerical techniques to simulate the transition from Maxwellian to non-Maxwellian distribution is developed [3-5]. At the same time in order to get the comprehensive description of plasma dynamics one should take care of plasma particles interaction, i.e. Coulomb collisions in Maxwellian/nonMaxwellian environment. The crucial point is the fact that the approach to describe the non-Maxwellian plasma relaxation through collisions should be introduced. That could be done via discretized collision operator developed for the test particle tracing approach. This operator was introduced in the paper [6] for the pitch-angle scattering and the energy slowing down and scattering. Later it was extended to different plasma species [7], and its validity to trace heavy impurities in fusion plasmas was shown in [8]. The significant constraint put in this operator is the isotropic Maxwellian distribution of the background plasmas.

In this paper the applicability of the discretized collision operator to non-Maxwellian plasma is extended. Starting from the Fokker-Planck collision operator, which includes Rosenbluth potentials, we derive new expressions for the discretized operator of a general Monte Carlo equivalent form in terms of expectation value and standard deviation including an arbitrary shape of distribution function for bulk plasma.

The modification of transport coefficients of impurity ions caused by the transition from the background plasma Maxwellian to non Maxwellian distribution functions is studied by means of test particle approach. For this purpose, the set of monoenergetic neon test impurities are followed in a toroidal plasma consisting of deuterons and electrons. The collisional interaction of impurities with main plasma is modeled by a discritized collision operator derived for an arbitrary distribution functions. The non Maxwellian distribution is obtained by adding a fraction of energetic particles of the same species as plasma. It is demonstrated that a change of collision frequencies of impurities takes place in presence of this energetic fraction of particles leading to a change of impurity neoclassical transport regime.

\section{TEST PARTICLE APPROACH}

A test particle approach is an idealized model of an object whose physical properties are considered to be negligible except of those sufficient to impact the rest of the system. Concerning plasma physics, in simulations with electromagnetic fields and Coulomb collisions the most important characteristics of a test particle become its electric charge and its mass. As to the fusion magnetized plasma, in order to describe test particle motion [9] one could integrate Newton's equation with the Lorentz force to trace the exact particle trajectory 


$$
m_{a} \frac{d \mathbf{v}}{d t}=Z_{a} e \mathbf{E}+\frac{Z_{a} e}{c}[\mathbf{v} \times \mathbf{B}], \quad \frac{d \mathbf{x}}{d t}=\mathbf{v},
$$

where $m_{a}$ is the test particle mass, $Z_{a} e$ is its charge, $\mathbf{E}$ and $\mathbf{B}$ are the electric field vector and magnetic induction respectively. On the other hand, the guiding center equation of the form

$$
\begin{gathered}
\mathbf{v}_{g}=\mathbf{v}_{\|} \frac{\mathbf{B}}{B}+\frac{c}{B^{2}}[\mathbf{E} \times \mathbf{B}]+\frac{m_{a} c\left(2 \mathrm{v}_{\|}^{2}+\mathrm{v}_{\perp}^{2}\right)}{2 Z_{a} e B^{3}}[\mathbf{B} \times \nabla B]+ \\
+\frac{m_{a} c \mathrm{v}_{\|}^{2}}{Z_{a} e B^{4}}[[\mathbf{B} \times \operatorname{rot} \mathbf{B}] \times \mathbf{B}],
\end{gathered}
$$

could be used to calculate guiding center trajectory [10] in the assumption that the Larmor radius is small comparing to the characteristic lengths of the inhomogeneity of the background plasma. Here $v_{\|}$and $\mathrm{v}_{\perp}$ are the parallel and perpendicular components of test particle velocity with respect to the magnetic field line direction. The equation (2) should be backed with the particle energy conservation low $W \equiv m_{a}\left(\mathrm{v}_{\perp}^{2}+\mathrm{v}_{\|}^{2}\right) / 2+Z_{a} e \Phi=$ const and conservation of perpendicular invariant of motion $\mu \equiv \mathrm{v}_{\perp}^{2} / B=$ const . To complete the test particle motion description, the Coulomb collisions should be included. The idea is that each integration time step the particle suffers a number of collisions that leads to modification of kinetic energy and additional modification of velocity vector direction. This effect could be described by discretized collision operator acting on the test particle after each integration step.

\section{DISCRETIZED COLLISION OPERATOR}

The Fokker-Planck collision operator acting on distribution function $f_{a}(\mathbf{v})$ of an arbitrary test particle species (a) under the assumption of isotropy for the distribution function $f_{b}\left(\mathbf{v}^{\prime}\right)$ of background plasma species (b) could be rewritten as follows

$$
\begin{array}{r}
\frac{d f_{a}}{d t}=v_{d}(\mathrm{v}) \mathrm{L}_{\mathrm{C}}+\frac{1}{\mathrm{v}^{2}} \frac{\partial}{\partial \mathrm{v}}\left[\mathrm { v } ^ { 3 } \left(\frac{m_{a}}{m_{a}+m_{b}} v_{S}(\mathrm{v}) f_{a}+\right.\right. \\
\left.\left.+\frac{1}{2} v_{\|} \mathrm{v} \frac{\partial f_{a}}{\partial \mathrm{v}}\right)\right],
\end{array}
$$

where $\mathrm{L}_{\mathrm{C}}=\frac{1}{2} \frac{\partial}{\partial \lambda}\left[\left(1-\lambda^{2}\right) \frac{\partial f_{a}}{\partial \lambda}\right]$ is Lorenz collision operator, $\quad \mathrm{L}^{\mathrm{ab}}=\ln \Lambda\left(4 \pi Z_{a} Z_{b} e^{2} / m_{a}\right)^{2}$ is function of Coulomb logarithm $\ln \Lambda$, charge numbers $Z_{a}$ and $Z_{b}$, and the mass $m_{a} \cdot \quad v_{S}=\mathrm{L}^{\mathrm{ab}} / \mathrm{v}\left(1+m_{a} / m_{b}\right) \partial \varphi_{b} / \partial \mathrm{v}$, $v_{d}=-2 \frac{\mathrm{L}^{\mathrm{ab}}}{\mathrm{v}^{3}} \frac{\partial \psi_{b}}{\partial \mathrm{v}}$ and $v_{\|}=-2 \frac{\mathrm{L}^{\mathrm{ab}}}{\mathrm{v}^{2}} \frac{\partial^{2} \psi_{b}}{\partial \mathrm{v}^{2}}$ are slowing down, deflection and parallel velocity diffusion frequencies respectively. The Rosenbluth potentials

$\varphi_{b}=-\frac{1}{4 \pi} \int \frac{1}{u} f_{b}\left(\mathbf{v}^{\prime}\right) d^{3} \mathbf{v}^{\prime}, \quad \psi_{b}=-\frac{1}{8 \pi} \int u f_{b}\left(\mathbf{v}^{\prime}\right) d^{3} \mathbf{v}^{\prime}$,

are functions of the relative velocity of particles $u=\left|\mathbf{v}-\mathbf{v}^{\prime}\right|$ and distribution function $f_{b}$.

The Monte Carlo equivalent of the collision operator of the general form expressed in terms of time derivative of expectation values and the square of the standard deviation reads

$$
F_{n}=F_{o}+d\langle F\rangle / d t \Delta \tau \pm \sqrt{\left(d \sigma_{F}^{2} / d t\right) \Delta \tau},
$$

where $\Delta \tau$ is integration time step and function $F$ could be replaced either by the kinetic energy of test particle $K=m_{a} \mathrm{v}^{2} / 2$ or by its pitch angle $\lambda=\mathrm{v}_{\|} / \mathrm{v}$. The sign \pm is to be chosen randomly but with the equal probability [6]. By definition, the expectation value is $\langle F\rangle=\int F f_{a} d F$, and its time derivative reads as $\frac{d\langle F\rangle}{d t}=\int F \frac{d f_{a}}{d t} d F+\int f_{a} \frac{d F}{d t} d F$, where the second term vanishes due to the fact of constant random variable values. Then the time derivative of square of standard deviation becomes $\frac{d \sigma_{F}^{2}}{d t}=\frac{d\left\langle F^{2}\right\rangle}{d t}-2\langle F\rangle \frac{d\langle F\rangle}{d t}$. Taking into account the derivative $d f_{a} / d t$ of the form (3) the analytical treatment under assumption of an arbitrary isotropic distribution function leads us to general expression for the energy slowing down and scattering operator

$$
\begin{aligned}
K_{n}=K_{0}-2 K_{0} \Delta \tau & \left(\frac{m_{a}}{m_{a}+m_{b}} v_{S}-\frac{5}{2} v_{\|}-\right. \\
& \left.-\left.K_{0} \frac{\partial v_{\|}}{\partial K}\right|_{K=K_{0}}\right) \pm 2 K_{0} \sqrt{v_{\|} \Delta \tau} .
\end{aligned}
$$

Now we are out of the possibility to derive the analytical form for the collision operator basing on arbitrary distribution function for the background plasma particles. Nevertheless, we can integrate numerically the expression (6) for any shape of bulk distribution and are able to study some special cases of the background plasma distribution function $f_{b}$.

\section{PLASMA DISTRIBUTION FUNCTION AND COLLISION FREQUENCIES}

For the simulation we choose the simple TOKAMAK toroidal field model with the major radius $\mathrm{R}_{0}=300 \mathrm{~cm}$, the minor radius $\mathrm{r}_{\mathrm{a}}=130 \mathrm{~cm}$ and on-axis magnetic field $\mathrm{B}_{0}=3 \mathrm{~T}$. The model plasma profiles are displayed in Fig. 1. We consider two plasma distribution functions: one is pure Maxwellian distribution and the other is Maxwellian together with the energetic particle fraction presented as

$$
f_{b}(\mathrm{v})=n_{1} /\left(\pi^{3 / 2} \mathrm{v}_{1}^{3}\right) e^{-\left(\mathrm{v} / \mathrm{v}_{1}\right)^{2}}+n_{2} /\left(\pi^{3 / 2} \mathrm{v}_{2}^{3}\right) e^{-\left((\mathrm{v}-\mathrm{v}) / \mathrm{v}_{2}\right)^{2}},
$$
where $\mathrm{v}_{i}=\sqrt{2 T_{i} / m_{p}}$ (Fig. 2).

Both distribution functions are isotropic in velocity space. In the case of neon ions colliding with the pure Maxwellian plasma we can easily estimate the values of the deflection frequency relying upon the chosen plasma profiles. The values of for 1 and $50 \mathrm{keV}$ neon ions are plotted versus the minor radius on Fig. 3.

If we "inject" in plasma the energetic deuterium fraction with the mean velocity $\mathrm{V}$ related to the energy $3 \mathrm{keV}$ and temperature $100 \mathrm{eV}$ we observe the modification of collision frequencies [11]. The variation of due to different energetic fraction density values $n_{2}$, 
which vary from $2 \%$ up to $10 \%$ of initial plasma density $n 1$, is presented on Fig. 4.

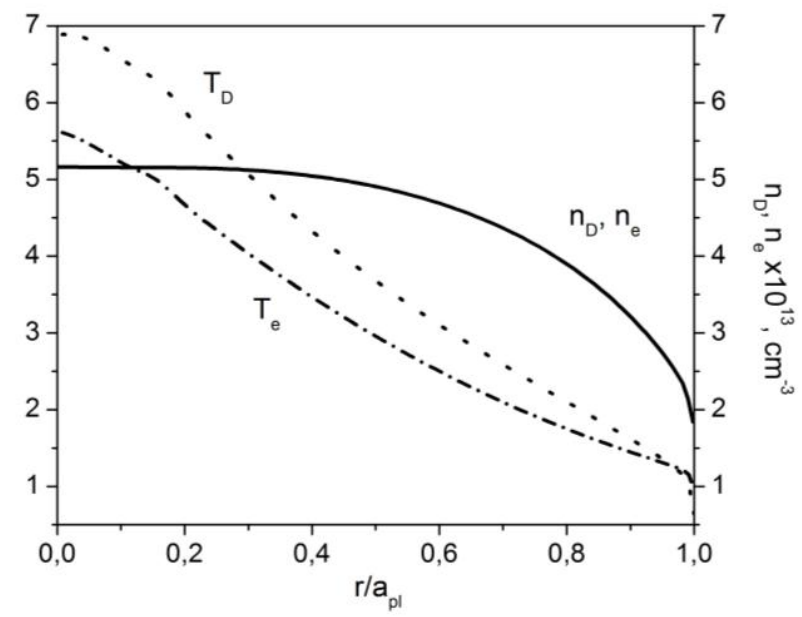

Fig. 1. Model profiles for the plasma consisting of deuterons and electrons

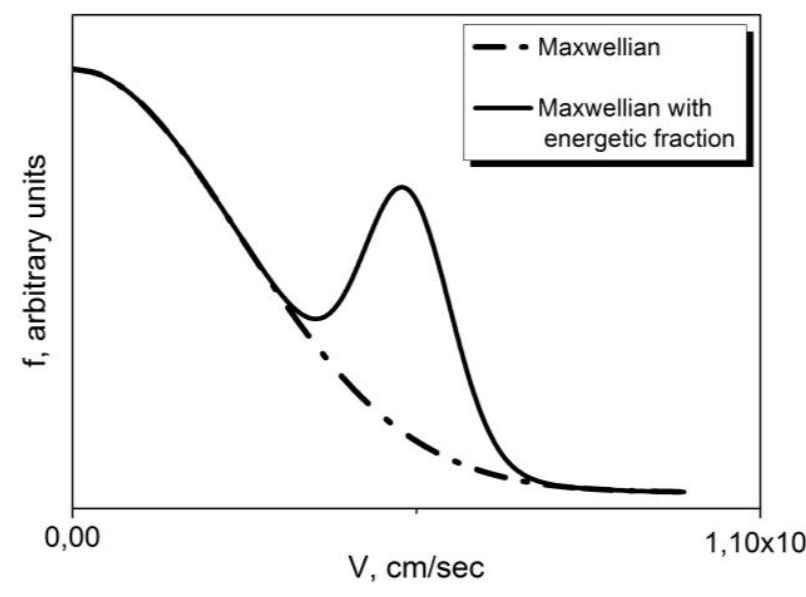

Fig. 2. Background deuterium distribution functions. Maxwellian and Maxwellian with the energetic deuterium fraction

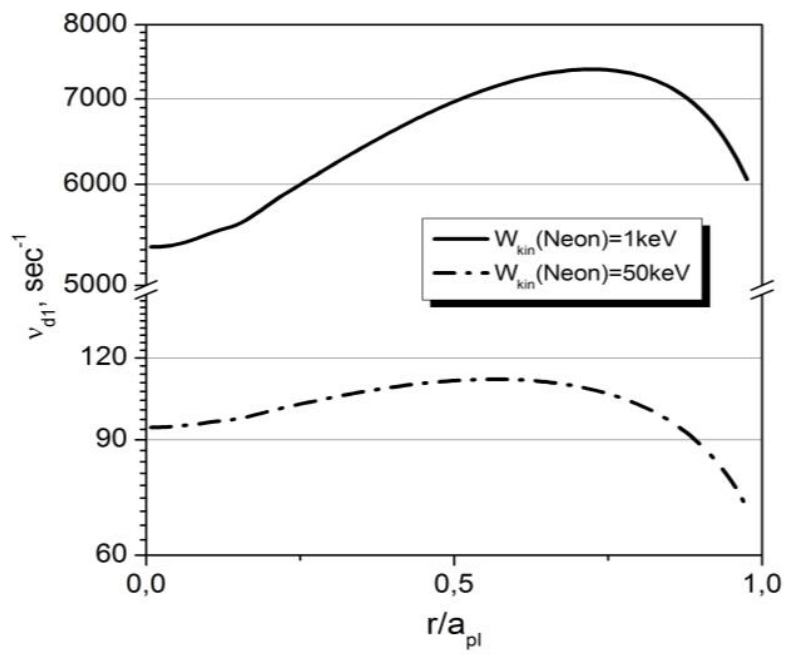

Fig. 3. Collision frequencies of neon impurity with the energies $1 \mathrm{keV}$ and $50 \mathrm{keV}$ in Maxwellian plasma versus the minor plasma radius

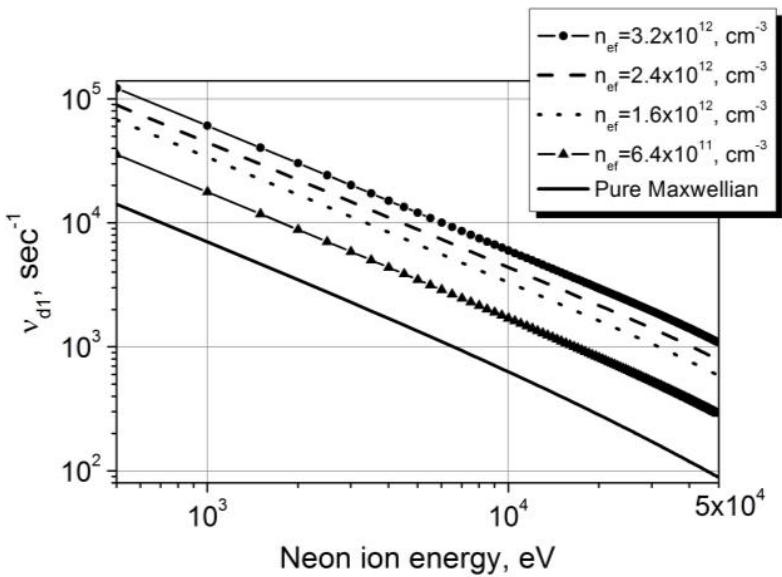

Fig. 4. Collision frequencies of test neon impurity in plasma without/with the energetic particle fraction of different parameters versus the neon ion energy

\section{IMPURITY DIFFUSION COEFFICIENTS}

The mean values of running monoenergetic diffusion coefficients of neon impurities are plotted on Figs. 5a and 5b. In case of Maxwellian plasma the collision frequencies very in the ranges $5350<v_{d 1}<7390$ and $70<v_{d 1}<110$ for 1 and $50 \mathrm{keV}$ neon ions respectively (see Fig. 3). These collision rates are pointed in Figs. 5a, 5,b with dark yellow ovals. For the non Maxwellian distribution we still stay within the same neoclassical transport model but with modified collision frequencies, which increase following the increase of the fraction of energetic particles (see Fig. 4). This modification leads to a shift between different neoclassical transport regimes. On Fig. 5a with the red arrow the shift of regime for $1 \mathrm{keV}$ neon impurities in the plasma with $2 \%$ density of energetic fraction is shown. Further increasing of density $\mathrm{n}_{2}$ leads to the more significant shift towards high rates of Pfirsch-Schlüter regime. The same tendency is observed for the neon impurities with the energy $50 \mathrm{keV}$ (see Fig. 5b).

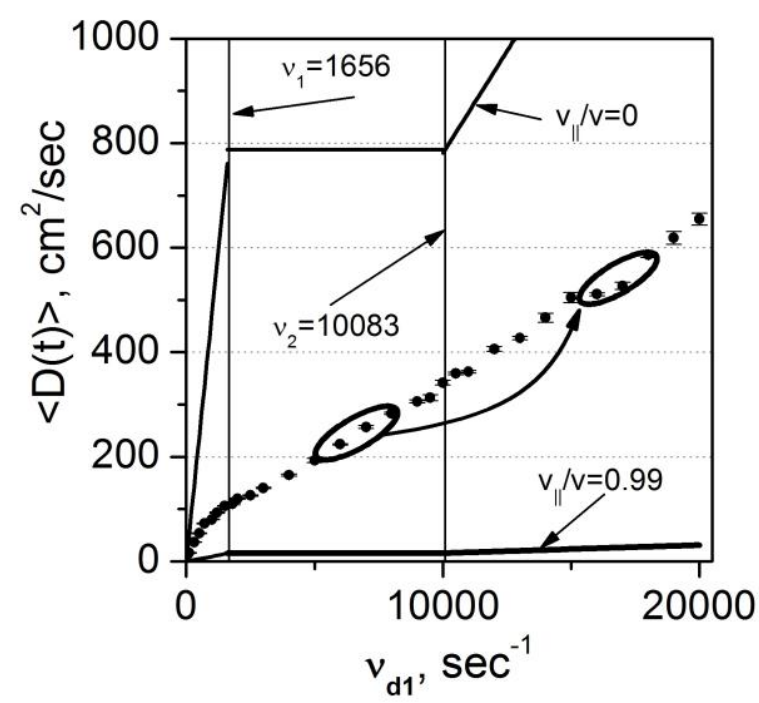

Fig. 5a. Mean values of monoenergetic diffusion coefficient of neon ion with versus the deflection frequency 


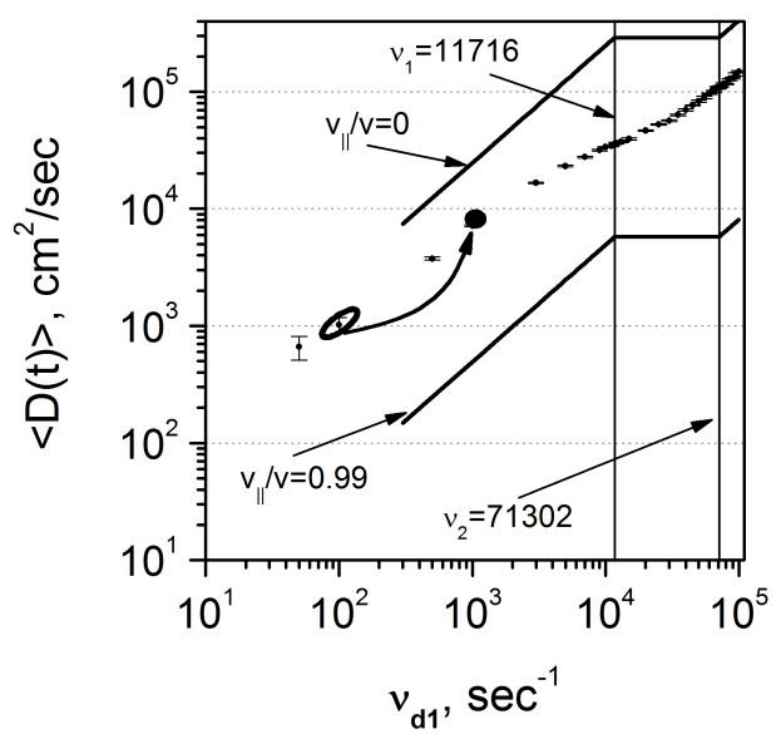

Fig. 5b. Mean values of monoenergetic diffusion coefficient of neon ion with different values of kinetic energy (1 keV and $50 \mathrm{keV}$ on figures Figs. 5, a, 5,b) and

b) respectively) versus the deflection frequency. The standard neoclassical values of diffusion coefficient for the possible smallest and largest values of neon Larmor radius respectively. The collision rates $v_{1}$ and $v_{2}$ are related to the boundaries between Galeev-Sagdeev, plateau and Pfirsch-Schlüter regimes in standard neoclassical theory

\section{CONCLUSIONS}

The integration of equations of motion (1) and (2) together with the collision operator that is called discretized collision operator (5) completes the description of test particle motion in fusion collisional plasma.

Starting from the Fokker-Planck collision operator (3) the general form of discretized collision operator for kinetic energy slowing down and scattering (6) is obtained. It includes the collision frequencies expressed via Rosenbluth potentials in general integral form (4).

The crucial point is the fact that the only assumption made for this derivation is the isotropy of the distribution function of bulk plasma in velocity space. Hence the distribution depends only on the value of the velocity but not on its direction $f_{b}\left(\mathbf{v}^{\prime}\right) \rightarrow f_{b}\left(\mathrm{v}^{\prime}\right)$. No any other assumption on the shape of bulk distribution function is made in operator (6).

It is shown that in presence of the energetic fraction the diffusion coefficients of the impurities vary due to modification of collision frequencies.

This modification which depends on the impurity energy and the parameters of the energetic particle fraction brings the impurities in different neoclassical transport regimes.

The phenomenon demonstrated by our simulations plays an important role for the impurity transport problem in non Maxwellian plasma. Such plasma is observed in modern fusion devices due to magnetic field lines reconnection, particle injection and plasma heating.

\section{ACKNOWLEDGEMENTS}

This work has been carried out within the framework of the EUROfusion Consortium and has received funding from the Euratom research and training programme 2014-2018 and 2019-2020 under grant agreement № 633053. The views and opinions expressed herein do not necessarily reflect those of the European Commission.

\section{REFERENCES}

1. J. Garcia et al. Key impact of finite-beta and fast ions in core and edge tokamak regions for the transition to advanced scenarios // Nucl. Fusion. 2015, v. 55, p. 053007.

2. J. Citrin et al. Nonlinear Stabilization of Tokamak Microturbulence by Fast Ions // Phys. Rev. Lett. 2013, v. 111, p. 155001

3. R. Dumont, Variational approach to radiofrequency waves in magnetic fusion devices // Nucl. Fusion. 2009, v. 49 , p. 075033.

4. J. Garcia et al. Critical Threshold Behavior for Steady-State Internal Transport Barriers in Burning Plasmas // Phys. Rev. Lett. 2008, v. 100, p. 255004.

5. O.A. Shyshkin et al. Ignition Analysis for D Plasma with Non-Maxwellian 3He Minority in Fusion Reactors // Plasma Fusion Res. 2011, v. 6, p. 2403064.

6. A.H. Boozer, G. Kuo-Petravic. Monte Carlo evaluation of transport coefficients // Phys. Fluids. 1981 , v. 24 , p. 851.

7. W.D. D'haeseleer, C.D. Beidler. An efficient physicsbased Monte Carlo algorithm for simulating alphaparticle orbits in tokamak fusion-reactor plasmas with toroidal-field ripple // Comput. Phys. Comm. 1993, v. 76, p. 1.

8. O.A. Shyshkin, R. Schneider, and C.D. Beidler. Numerical analysis of tungsten transport in driftoptimized stellarator with ergodic and nonergodic plasma configurations // Nucl. Fusion. 2007, v. 47, p. 1634.

9. B.A. Trubnikov. Particle interactions in a fully ionized plasma // Reviews of Plasma Physics / M.A. Leontovich, New York: Consultant Bureau, 1965, v. 1, p. 105.

10. D.V. Sivukhin, Motion of charged particles in electromagnetic fields in the drift approximation // Reviews of Plasma Physics / M.A. Leontovich, New York: Consultant Bureau, 1965, v. 1, p. 1.

11. O.A. Shyshkin, B. Weyssow // 35th EPS Conference on Plasma Phys. Hersonissos, 9-13 June 2008 ECA v. 32D, p-4.031.

Article received 25.10.2020 


\title{
МОДЕЛИРОВАНИЕ ПЕРЕНОСА НЕМАКСВЕЛЛОВСКОЙ ПЛАЗМЫ МЕТОДОМ ТЕСТОВЫХ ЧАСТИЦ: ДИСКРЕТНЫЙ СТОЛКНОВИТЕЛЬНЫЙ ОПЕРАТОР
}

\author{
Д.В. Вознюк, О.А. Шишкин, И.А. Гирка
}

Плазма, наблюдаемая в современных термоядерных установках, очень часто характеризуется сильно немаксвелловской функцией распределения. Такое распределение является непосредственным результатом неизбежного применения методов нагрева плазмы, таких как инжекция нейтрального пучка (NBI) и ионноэлектронный циклотронный резонансный нагрев (ICRF/ECRF), которые приводят к появлению немаксвелловских быстрых ионов. Другой причиной перехода от максвелловской к немаксвелловской функции распределения является пересоединение силовых линий магнитного поля с последующим образованием магнитно-резонансных структур, таких как магнитные острова и стохастические слои. Одним из основных подходов, используемых для моделирования термоядерной плазмы, является метод тестовых частиц, основанный на решении уравнений движения тестовых частиц. Чтобы получить полное описание поведения плазмы в таких условиях, необходимо учесть взаимодействие между частицами, а именно кулоновские столкновения в немаксвелловской среде. В данной работе представлено полное выражение для дискретного столкновительного оператора в общей эквивалентной форме Монте-Карло с использованием ожидаемой величины и квадрата стандартного отклонения для произвольной немаксвелловской функции распределения фоновой плазмы. С помощью этого дискретного оператора столкновений изучается изменение коэффициентов переноса примесных ионов, вызванное переходом фоновой плазмы от максвелловской к немаксвелловской. С этой целью отслеживается набор тестовых примесей моноэнергетического неона в тороидальной фоновой плазме, состоящей из дейтронов и электронов. Немаксвелловское распределение фоновой плазмы получается путем добавления фракции энергетических частиц одного и того же вида. Показано, что при наличии этой энергетической фракции происходит изменение частот столкновений примесей, приводящее к смене неоклассического режима переноса примеси.

\section{МОДЕЛЮВАННЯ ПЕРЕНОСУ НЕМАКСВЕЛІВСЬКОЇ ПЛАЗМИ МЕТОДОМ ТЕСТОВИХ ЧАСТИНОК: ДИСКРЕТНИЙ ОПЕРАТОР ЗІТКНЕНЬ}

\section{Д.В. Вознюк, О.О. Шиикін, І.О. Гірка}

Плазма, що спостерігається в сучасних пристроях керованого термоядерного синтезу, дуже часто характеризується немаксвелівською функцією розподілу. Такий розподіл є безпосереднім результатом неминучого застосування методів нагріву плазми, таких як інжекція нейтрального пучка (NBI) i ioнноелектронний циклотронний резонансний нагрів (ICRF/ECRF), які призводять до появи немаксвелівських швидких іонів. Іншою причиною переходу від максвелівської до немаксвелівської функції розподілу $є$ перез'єднання силових ліній магнітного поля з подальшим утворенням магнітно-резонансних структур, таких як магнітні острови і стохастичні шари. Одним з основних підходів, що використовуються для моделювання термоядерної плазми, є метод тестових частинок, заснований на вирішенні рівнянь руху тестових частинок. Щоб отримати повний опис поведінки плазми в таких умовах, необхідно врахувати взаємодію між частинками, а саме - кулонівські зіткнення в немаксвелівському середовищі. У даній роботі представлено повне вираження для дискретного оператора зіткнень у загальній еквівалентній формі МонтеКарло 3 використанням величини очікування і квадрата стандартного відхилення для довільної немаксвелівскої функції розподілу фонової плазми. За допомогою цього дискретного оператора зіткнень вивчається зміна коефіцієнтів переносу домішкових іонів, яка викликана переходом фонової плазми від максвелівської до немаксвелівскої. Для цього відстежується набір тестових домішок моноенергетичного неону в тороїдальній фоновій плазмі, що складається 3 дейтронів і електронів. Немаксвелівський розподіл фонової плазми отримано шляхом додавання фракції енергетичних частинок одного і того ж виду. Показано, що при наявності цієї енергетичної фракції відбувається зміна частот зіткнень домішок, що призводить до зміни неокласичного режиму переносу домішок. 